\title{
$\Psi$
}

\section{Problem Psikologis Dan Strategi Coping Pelaku Upacara Kematian Rambu Solo' di Toraja (Studi fenomenologi pada tana' bulaan )}

\begin{abstract}
ABSTRAK Penelitian ini bertujuan untuk memahami dinamika psikologis subjek dengan cara memahami faktor motivasional individu dari tana' bulaan miskin dalam melaksanakan upacara rambu solo', beban keuangan sebagai kejadian menekan yang mereka hadapi, strategi pengatasan masalah dan dampak psikologis pada tana' bulaan miskin. Penelitian ini adalah penelitian kualitatif dengan pendekatan fenomenologi. Subjek penelitian sebanyak 4 orang yang melaksanakan upacara rambu solo' tingkat sempurna, sedang, dan minim serta 7 orang informan. Metode analisis mengacu pada Moustakas (1994) yaitu : deskripsi pemahaman fenomena, reduksi dan eliminasi, pengelompokkan tema dan deskpripsi individu terhadap fenomena. Hasil temuan penelitian

ini adalah: a) faktor-faktor yang mendorong pelaksanaan upacara rambu solo' merupakan upaya individu untuk memenuhi kebutuhan dasar dalam dirinya, yaitu kebutuhan untuk survive, love and belonging, power, dan freedom. b) Keputusan terlibat membuat para pelaku menghadapi dampak langsung dan dampak tidak langsung dari beban keuangan rambu solo'. c) Dalam menghadapi beban keuangan rambu solo' sebagai stresor, Strategi coping yang dilakukan para pelaku, utamanya pelaku upacara rambu solo' besar, cenderung mengalami penurunan secara bertahap dari coping berfokus pada masalah kemudian beralih pada coping berfokus pada emosi dan dari coping adaptif beralih pada coping maladaptif. (d) dampak psikologis yang ditemukan: stres, ketakutan (kecemasan), depresi ringan. (e) dinamika psikologis pelaku upacara rambu solo' sangat kompleks, sebagai pilihan dari proses internal, beban keuangan rambu solo' dinilai subjek sebagai konsekuensi dan untuk itu mereka berupaya

mencari kebutuhan-kebutuhan yang sama atau berbeda yang adekuat atas deprivasi kebutuhan dasar dalam dirinya.
\end{abstract}

KATA KUNCI: rambu solo', tana' bulaan, beban keuangan, problem psikologis.

\section{Arman Marwing}

Alumnus Program Pascasarjana Universitas Gadjah Mada Yogyakarta Email:armenia_mapk85@yahoo.com

PSIKOISLAMIKA, Jurnal Psikologi Islam (JPI) Copyrigth @ 2011 Lembaga Penelitian Pengembangan Psikologi dan Keistamalin (LP3K). Vol 8 No. 2, Januari 2011 209-230

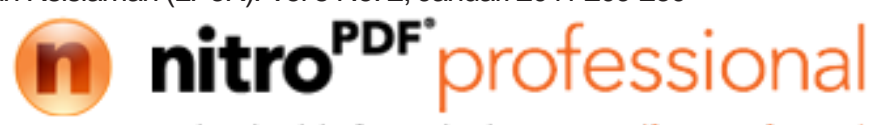




\section{Muqadimah}

Kematian orang tua merupakan peristiwa yang lazim dialami banyak individu terutama bagi anak-anak yang telah dewasa. Meskipun demikian, bagi seluruh anggota keluarga yang ditinggalkan, kematian merupakan peristiwa yang sangat menekan yang harus mereka hadapi (Parkes, 2001).

Menurut Fan \& Zick (2004), bagi keluarga yang ditinggalkan mati umumnya tekanan ekonomi yang berkaitan dengan pengeluaran rumah tangga, keperluan-keperluan, makanan, pakaian dan transportasi relatif lebih stabil pada bulan-bulan kematian orang tua akan tetapi justru pengeluaran yang terbesar adalah pada saat perawatan medis dan utamanya perencanaan penguburan dan pemakaman.

Resiko beban keuangan dari upacara pemakaman bagi keluarga miskin yang ditinggalkan orang tuanya nampak lebih serius terjadi pada negara-negara berkembang terlebih jika dalam konteks budaya sosial-budaya setempat, upacara pemakaman menempati posisi yang sangat penting dan kompleks. Keadaan ini seperti halnya yang tergambar dalam kehidupan individu suku Toraja yang ditinggal mati oleh orang tuanya.

Dalam memandang kematian, kepercayaan nenek moyang orang Toraja telah menggariskan status kasta atau tana' yang meninggal sebagai rujukan dari pelaksanaan ketentuan adat bukan berdasarkan pertimbangan ekonomi pelakunya (Kobong, 2008). Ketentuan tersebut cukup problematis saat ini, mengingat perubahan sosial ekonomi juga terus terjadi di Toraja sebagaimana yang terjadi di tempat lainnya. Jika dahulu upacara rambu solo' yang mewah dan mahal cukup relevan bagi tana' bulaan yang kala itu selalu diidentikkan dengan pemilik tanah dan hewan ternak. Maka, dengan adanya perubahan sosial-ekonomi tersebut keadaan mereka kini telah jauh berubah, beberapa dari kalangan tersebut hanya dapat hidup sederhana bahkan sebagian lainnya justru berada dalam kondisi miskin secara ekonomi.

Keadaan ini pulalah yang membuat banyak diantara mereka hidup dalam kemiskinan dan secara nyata tidak dapat dipungkiri kehidupan para pelakunya menjadi semakin terbebani secara ekonomi lantaran harus menjalankan ritus tersebut. Meski bagi orang Toraja , rambu solo' merupakan pesta adat yang membanggakan. Namun, dampaknya di kemudian hari menimbulkan beban hutang " tujuh. 
turunan" bagi mereka yang melaksanakannya (Tempo, 2001).

Gambaran tana' bulaan miskin seperti yang dikemukakan di atas konsekuensinya kurang menguntungkan bahkan sampai menimbulkan problem psikologis,seperti stres, kecemasan dan dampak lainnya. Meski demikan, sampai saat ini masih banyak para pelaku dari tana' bulaan yang tetap berupaya untuk melaksanakan upacara rambu solo' sesuai dengan ketentuan adat bagi orang tuanya yang meninggal.

Berdasarkan uraian di atas, hal menarik yang ingin peneliti kaji lebih lanjut adalah keputusan terlibat dalam upacara rambu solo' yang juga dilandasi oleh berbagai motif dan keinginan pelaku, berlanjut pada konsekuensi beban keuangan sebagai kejadian menekan, strategi pengatasan masalah yang digunakan serta problem psikologis pelaku upacara rambu solo' pada tana' bulaan, menjadi titik tolak perhatian peneliti.

Berdasarkan uraian latar belakang masalah yang telah dikemukakan, maka rumusan masalah penelitian adalah bagaimana dinamika problem psikologis dan coping pelaku upacara rambu solo' pada tana' bulaan?

\section{Kerangka Kerja Teoritik}

Kejadian menekan merupakan peristiwa yang dipersepsikan individu sebagai stresor yang mengancam dan membahayakan, membuat perasaan tidak nyaman dan tertekan (Rahmawati, 2006). Kejadian menekan sebagai stresor adalah suatu bagian yang alamiah dalam hidup setiap orang sehingga stres diartikan secara berbeda pula pada setiap orang. Oleh karena itu, pengalaman traumatis dan menekan memiliki dampak pada kesejahteraan psikologis menekankan kepada peran penegah dari reaksi coping yang diberikan (Pastò, McCreary, \& Thompson, 2000).

Beban keuangan upacara kematian dalam pelbagai budaya merupakan stressor yang paling lazim. Setidaknya, deksripsi Fan dan Zick (2004) mengenai tekanan ekonomi terbesar bagi keluarga yang ditinggalkan berkaitan dengan perawatan medis dan utamanya perencanaan penguburan dan pemakaman tidak dapat dipungkiri.

Terkait dengan beban keuangan pemakaman tradisional di berbagai daerah dapat terwakilkan dengan penelitian yang dilakukan Hayes (dalam Buger, 2004), terhadap suku-suku di Afrika Selatan. Dalam penelitian itu, la menyatakan bahwa beberapa 
anggota keluarga di daerah tersebut, menghabiskan tiga kali lipat total pemasukan bulanan rumah tangga mereka, untuk pelaksanaan upacara pemakaman. Hal yang paling mencolok adalah komunitas miskin sedang menyalurkan banyak uang kepada orang yang meninggal, sementara mereka sendiri merupakan penyintas yang menderita kemiskinan.

Konsep penting yang erat berhubungan dengan ide sistem dalam psikologi klinis adalah konsep stres. Istilah stres identik dengan suatu keadaan yang tertekan, baik secara fisik maupun psikologis (Chaplin, 1997). Keadaan tersebut merupakan respon tubuh yang sifatnya tidak spesifik terhadap setiap tuntutan beban yang dikenakannya (Selye dalam Hawari, 2002).

Mendukung pendapat tersebut, Crider, Goethal, Kavanough, dan Solomon (1983) menyatakan bahwa stres merupakan suatu pola tertentu yang diperoleh dari reaksi psikologis dan fisiologis yang mengganggu dan timbul dari stimulus-stimulus tertentu di lingkungan individu sehingga mengancam kebutuhan-kebutuhan utamanya dan memaksa individu untuk melakukan coping sesuai dengan kemampuan yang dimiliki.

Stres sebagai suatu reaksi individu terhadap tuntutan lingkungan dapat bersumber dari berbagai aspek. Salah satu di antaranya dikemukakan oleh Hardiman (dalam Rahmawati, 2006), sumber stres yaitu :

a. Fisiologis seperti infeksi, penganiayaan fisik, dan kelelahan fisik.

b. Psikologis seperti kegagalan, rasa tidak puas, frustrasi, merasa bersalah dan konflik.

c. Sosial seperti perubahan sosial, nilai-nilai budaya, kesenjangan keluarga dan persaingan dalam pekerjaan.

Diantara berbagai model teoritis dari strategi coping yang ada, Maka, penelitian ini mencoba merujuk kepada teori coping yang dikemukakan oleh Carver, Scheier, dan Weintraub (1989). Hal ini karena teori coping yang dikemukakan keduanya lebih bervariasi dan meluas dalam menjabarkan tipe-tipe copingnya dibandingkan dengan pengkategorian dari model teoritis coping yang ada. Menurut Carver dkk (1989), Strategi pengatasan masalah terdiri dari dua bentuk, yaitu strategi pengatasan masalah yang berorientasi pada masalah dan yang berorientasi pada emosi. Kedua bentuk coping tersebut dapat dijabarkanseblagahberikut : 
1. Strategi pengatasan masalah yang berorientasi pada masalah.

Carver dkk (1989) menyatakan bahwa aspek-aspek strategi pengatasan masalah yang berorientasi pada masalah (problem focus coping) adalah:

a) Perilaku aktif (active coping), merupakan proses pengambilan langkah-langkah aktif untuk mencoba memindahkan, menghindari tekanan dan memperbaiki dampaknya.

b) Perencanaan (planning), adalah memikirkan bagaimana mengatasi tekanan, memikirkan tindakan yang diambil dan menentukan cara penanganan terbaik untuk memecahkan masalah.

c) Penyempitan dalam wilayah bidang fenomena individu (Suppresion of competing). Individu dapat menahan diri untuk menahan alur informasi yang bersifat kompetetitif agar bisa berkonsentrasi penuh pada masalah yang dihadapi.

d) Pengekangan diri (restraint coping), merupakan suatu respon yang bersifat menahan diri yang bermanfaat dan diperlukan untuk mengatasi tekanan.

e) Mencari dukungan sosial (seeking social support for instrumental reasons), adalah upaya untuk mencari dukungan sosial, seperti mencari nasihat, informasi, dan bimbingan.

f) Mencari dukungan sosial secara emosional (seeking social support for emotional reasons), merupakan upaya untuk mencari dukungan sosial, seperti mendapat dukungan moral, simpati atau pengertian.

2. Strategi pengatasan masalah yang berorientasi pada emosi (emotional focus coping).

Menurut Carver dkk (1989) aspek yang termasuk dalam strategi pengatasan masalah yang berorientasi pada emosi adalah sebagai berikut:

a) Berpikir positif dan pertumbuhan (positive reinterpretation and growth), adalah penanggulangan masalah yang ditujukan untuk mengatasi tekanan emosi daripada dengan tekanan itu sendiri.

b) Penerimaan (acceptance), merupakan sebuah respon SMM secara fungsional, adengath dugaan bahwa individu yang 
menerima kenyataan yang penuh tekanan dipandang sebagai individu yang berupaya untuk menghadapi situasi yang terjadi.

c) Kembali pada agama (turning to religion), merupakan upaya yang dilakukan individu untuk kembali pada agama, ketika berada pada tekanan.

d) Berfokus pada pengekspresian perasaannya (focus on and venting emotion), merupakan upaya yang dilakukan individu dengan cara mengekspresikan perasaannya.

e) Penyangkalan (denial), merupakan respon SMM individu dengan menolak atau menyangkal suatu realita.

f) Penyimpangan perilaku (behavioral disengagement), yaitu kecenderungan untuk menurunkan upaya dalam mengatasi tekanan, bahkan menyerah atau menghentikan upaya untuk mencapai tujuan.

g) Penyimpangan mental (mental disengagement), yang terjadi melalui suatu variasi aktivitas yang luas yang memungkinkan terhalangnya individu untuk berfikir tentang dimensi perilaku dan tujuan. Menggunakan aktivitas alternatif untuk melupakan permasalahan, seperti melamun, tidur atau menenggelamkan diri dengan menonton TV.

h) Penyimpangan dalam penggunaan alkohol (alcoholdrug disengagement), merupakan upaya yang dilakukan seseorang untuk menghilangkan tekanan melalui pemakaian obat-obatan atau minum minuman keras.

Beberapa review penelitian internasional mengenai pekabungan dan proses duka cita menemukan bahwa tekanan keuangan dan ketidakpastian ekonomi dapat menjadi faktor bebas yang beresiko terjadinya depresi dan distress dari partner yang meninggal (M. Stroebe, Schut, \& W. Stroebe, 2007). Mereka meminta adanya evaluasi pengaruh keuangan dan sumber daya material secara lebih lanjut mengenai proses duka cita, termasuk dukungan strategi coping individu, dan prediksi akibat atau hasil psikologis (Stroebe, Folkman, Hansson, \& Schut, 2006).

\section{Upacara Kematian Rambu Solo'}

Menurut Tulak (2009), Pada dasarnya rambu solo' itu sendiri Created with

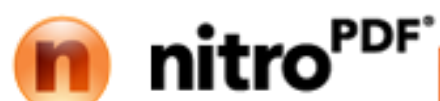


merupakan upacara pemakaman adat Toraja dimana para leluhur menyebutnya dengan istilah rambu solo' yang berarti hati yang sedang menurun karena penuh duka dan sedih. Dalam pelaksanaannya sejatinya di dasarkan pada struktur sosial, yaitu a) Tana' bulaan (bangsawan), b) Tana' bassi (bangsawan menengah), c) Tana' karurung (golongan tukang, pekerja terampil), dan d) Tana' kua kua atau kalangan hamba (Kobong, 2008). Meskipun saat ini terdapat pula faktor-faktor sosial-ekonomi yang turut menentukan,pelaksanaan upacara rambu solo', faktor-faktor tersebut hanya bersifat sekunder dan faktor struktur sosial masih menjadi hal yang sangat dominan dan berpengaruh.

Proses psikologis upacara kematian dapat ditelaah melalui analisis teori psikologi klinis yang mengkaji aspek individual utaamanya yang berkaitan dengan keterlibatan para pelaku dalam upacara kematian rambu solo' di Toraja. Teori psikologi klinis yang dimaksud adalah teori yang dikemukakan oleh William Glasser yang selanjutnya diberi nama choice theory.

Teori pilihan didasarkan pada asumsi bahwa semua keputusan perilaku individu yang terus-menerus dihubungkan dengan pemenuhan kebutuhan dasar manusia yang menurut Glasser terdiri atas lima hal, yaitu survival, love and belonging, power, freedom and fun. (Glasser, 1998).

Dalam penelitian ini terdapat beberapa pertanyaan penelitian untuk mengungkap tentang dinamika psikologis pelaku upacara rambu solo' pada tana' bulaan, yang diharapkan akan terjawab dalam temuan penelitian yaitu ;

1. Faktor-faktor apa sajakah yang melatar belakangi pelaku upacara tana' bulaan untuk tetap melaksanakan upacara adat rambu solo' sesuai dengan ketentuan adat?

2. Beban keuangan apa saja yang dialami pelaku upacara rambu solo' sebagai kejadian menekan?

3. Bagaimana strategi pengatasan masalah yang digunakan oleh pelaku upacara rambu solo' pada tana' bulaan?

4. Bagaimana problem psikologis pada pelaku upacara kematian rambu solo'?

\section{Metode Penelitian}

Pendekatan dalam penelitian ini menggunakan pendekatan fenomenologi yang sangattenhengedepankan individual differences 
(perbedaan individual). Penetapan subjek didasarkan pada kriteria sebagai berikut : (a) laki-laki dan perempuan dewasa yang telah menikah, (b) Usia antara 35-65 tahun, (c) Suku Toraja (d) Pernah atau sedang melaksanakan upacara kematian rambu solo' bagi orang tuanya (e) Tidak memiliki pekerjaan tetap atau memiliki pekerjaan yang hanya cukup untuk memenuhi kebutuhan dasar sehari-hari. Informan di bagi menjadi 2 yaitu informan tahu dan informan pelaku. Informan tahu adalah informan yang hanya mengetahui tentang subjek secara umum, sedangkan informan pelaku adalah informan yang merasakan dampak dari perilaku subjek. Dokumen tertulis dalam penelitian ini adalah data demografis dan geografis kampung panta' nakan lolo'termasuk catatan -catatan pribadi yang berkaitan dengan rambu solo' seperti catatan hutang atau petua' yang dimiliki. Dokumen tidak tertulis dalam penelitian ini berupa simbolsimbol yang yang dapat diamati pada subjek dan lingkungannya. Simbol - simbol yang dimaksud secara spesifik antara lain cara berpakaian subjek, tempat kerja atau tempat kumpul subjek, kondisi fisik subjek, dan keadaan lingkungan rumah tempat subjek tinggal. Penelitian ini dilaksanakan di ke'te kesu' yang berada di lembang panta' nakan lolo kecamatan Kesu', Kabupaten Toraja Utara. Perkampungan Ke'te Kesu' terletak empat kilometer sebelah tenggara kota Rantepao. Dalam penelitian ini, analisis dan interpretasi data yang digunakan adalah modifikasi metode Stevick- Colaizzi-Keen dari Moustakas (1994).

\section{Hasil dan Diskusi}

\section{Dinamika Motif/ Kebutuhan Pelaksanaan Upacara Rambu Solo'}

Temuan dalam penelitian ini menunjukkan bahwa dinamika kebutuhan yang ingin dipenuhi dari pelaksanaan upacara rambu solo' , pada setiap individu berbeda-beda, meskipun terdapat beberapa kebutuhan dominan yang hampir selalu ada pada keseluruhan subjek dalam penelitian ini, yaitu kebutuhan untuk bertahan hidup (need to survive). Hal tersebut sepert terlihat pada keinginan subjek TM untuk tidak miskin daging melalui pelaksanaan upacara rambu solo'. Motif agar tidak miskin daging ini, terkait tidak hanya dalam bentuk kebutuhan subjek secara fisik seperti makanan, tetapi juga ketersediaan atau jaminan daging bagi dirinya kelak.

Hal ini sejalan dengan pendapat Glasser (1998) bahwa, kebutuhan bertahan hidup tidak hanya meliputi kebutuhan akan makanan, tempat tinggal,kenyamanan fisik, dan keselamatan tetapi 
juga mengandung komponen psikologis, yaitu kebutuhan akan rasa tenang atau tentram (jaminan masa depan) dan keamanan (security) dalam hidup kita (Glasser, 1998).

. Hasil penelitian ini telah memperlihatkan adanya cultural belief atau local belief berupa keyakinan seluruh subjek, bahwa dengan melaksanakan upacara rambu solo'mereka telah menjadi manusia Toraja yang utuh (subjek TM dan DS) dan sebagai upaya menjaga sekaligus mempertahankan identitas mereka sebagai orang Toraja agar tidak hilang, dengan melestarikan upacara ini (subjek AS dan OB ). Singkatnya, sebagai orang Toraja, mereka akan merasa "mati" apabila tidak melaksanakan ritus kedukaan ini dan rambu solo' telah menjadi identitas diri mereka sebagai orang Toraja. Oleh karena alasan tersebut di atas, peneliti memasukkan kepatuhan terhadap ketentuan adat sebagai ekspresi kebutuhan untuk survive bagi orang Toraja. Hal ini sekaligus menguatkan tesis Glasser (2005) sendiri bahwa, Kebutuhan dasar kita secara revolusioner tetap, tetapi kebutuhan tersebut secara signifikan dimodifikasi oleh budaya, kepercayaan, dan pengalaman personal.

Selain kebutuhan untuk bertahan hidup di atas, Penelitian ini menemukan adanya kebutuhan-kebutuhan yang mendominasi dan mendasari respon-respon emosional dan behavioral para subjek yaitu kebutuhan akan disukai dan dimiliki pada sebagian besar subjek, kecuali subjek OB. Kebutuhan untuk disukai dan dimiliki tersebut dipenuhi melalui pelaksanaan rambu solo'. Pada Kasus TM, Melalui upacara besar, subjek berharap ia bisa membalas daging orang lain kepadanya dan membantu dirinya untuk mendapatkan persetujuan dan penerimaan yang TM dambakan.

Temuan lain dari penelitian ini juga menujukkan dominasi kebutuhan yang berbeda pada beberapa individu. Hal ini menurut Glasser (1998) karena setiap subjek memiliki pengalaman yang spesifik tentang bagaimana mereka memenuhi kebutuhannya. Terlihat beberapa kebutuhan seperti kebutuhan akan kuasa (need to power) lebih dominan ada pada kedua pelaku upacara rambu solo' dengan upacara yang besar (Subjek TM dan DS), sebaliknya dominasi kebutuhan akan kebebasan (need to freedom), justru lebih terlihat pada subjek yang memutuskan upacara yang standar minimal untuk tana' atau bahkan upacara rambu solo' yang minim (Subjek AS dan OB ).

Alasan yang paling jelas yang dapat menerangkan pembedaan kebutuhan antara keempât subjek tadi adalah bahwa perbedaan 
budaya, kepercayaan, dan pengalaman personal pelaku upacara rambu solo',sangat berperan dalam menentukan bagaimana mereka memenuhi kebutuhan dasar masing -masing (Glasser, 2005).

\section{Beban Keuangan Rambu Solo’Sebagai Kejadian Menekan}

Beban keuangan upacara kematian dalam pelbagai budaya merupakan stresor yang paling lazim. Setidaknya, deksripsi Fan dan Zick (2004) mengenai tekanan ekonomi terbesar bagi keluarga yang ditinggalkan berkaitan dengan perawatan medis dan utamanya perencanaan penguburan dan pemakaman tidak dapat dipungkiri. Beberapa temuan dalam penelitian ini telah menunjukkan bahwa beban keuangan rambu solo' bagi individu maupun rumah tangga secara signifikan membawa dampak ekonomi yang negatif bagi kesejahteraan individual maupun rumah tangga dalam jangka pendek maupun panjang.

Secara umum keseluruhan subjek dalam penelitian baik yang melaksanakan upacara yang besar, sedang (standar minimum untuk tana' bulaan), maupun upacara rambu solo' yang minim, memiliki kesamaan pengalaman kesulitan dalam menghadapi dampak langsung dari beban keuangan, yaitu tingginya biaya upacara rambu solo', tanggungan petua' sule, dan banyaknya hutang (informal). Namun demikian, perbedaaan beban keuangan rambu solo' pada masing -masing subjek, justru akan sangat tampak ketika melihat dampak dari dampak tidak langsung yang ditimbulkan. Terdapat indikasi bahwa dampak jangka panjang timbul sebagai implikasi dari ketidakmampuan subjek dalam mengatasi dan mengontrol permasalahan asal, yaitu beban keuangan rambu solo' sebagai stresor.

Pada subjek dengan upacara yang besar, seperti subjek TM dan DS, dampak ketidakmampuan dalam mengatasi permasalahan asal membuat, mereka mengalami keadaan yang tidak menyenangkan dari dampak tidak langsung dari beban keuangan rambu solo'. Dampak tidak langsung tersebut antara lain kehilangan aset dan bangkrutnya usaha, rendahnya pendidikan dan pekerjaan, pernikahan muda pada anak serta kesulitan untuk memenuhi kebutuhan sehari-hari. Khusus pada subjek TM, ditemukan dampak tambahan berupa perceraian serta kondisi kesehatan yang buruk .

Sebenarnya kondisi pada subjek TM, persis dengan yang dialami subjek AS, yângatmelaktakan upacara rambu solo' sedang

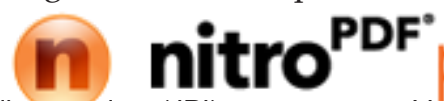

PSIKOISLAMKA, Jurnal Psikoluyı Islam (JPI) 
(standar minimal untuk tana' bulaan). Hanya saja, demografi berupa pekerjaan, pendidikan dan status pernikahan anak-anak subjek AS jauh lebih baik dibandingkan pada anak -anak TM dan DS. Hal ini dikarenakan hak asuh anak subjek AS, pasca perceraian diserahkan sepenuhnya kepada mantan isterinya, yang memiliki penghasilan tetap sebagai PNS di kota besar. Tentu saja kondisi tersebut memungkinkan anak-anak AS mendapat akses yang lebih baik.

Seperti yang telah dikemukakan sebelumnya, dampak jangka panjang rambu solo' juga terjadi pada pelaku upacara rambu solo' dengan upacara yang minim. Hanya saja bentuknya akan sangat berbeda. Kasus OB misalnya, merupakan kasus yang menarik. Selain berhadapan langsung dengan dampak langsung dari beban keuangan rambu solo', subjek OB juga harus berhadapan dengan dampak tidak langsung yang berat bagi dirinya, yaitu stigmatisasi dari masyarakat, yang biasanya akan berlanjut pada perbuatanperbuatan diskriminatif pada dirinya .

Pada subjek OB, dampak merugikan dari stigmatisasi membuatnya diabaikan oleh keluarga besarnya terutama yang kaya. Bahkan kedudukannya sebagai keturunan tana' bulaan di mata masyarakat, sudah tidak dihargai lagi. Kondisi ini tergambar dari begitu seringnya masyarakat kampung menjadikan upacara rambu solo" nya yang minim sebagai "bahan cerita" atau pegunjingan . Keadaan-keadaan tesebut membuat subjek kerapkali merasa terasing dan tidak enak hati serta minder, ketika dirinya harus berinteraksi dalam masyarakat dalam acara pelayatan, yang dianggap subjek sebagai kegiatan yang paling menyiksa dalam hidupnya. Apa yang dirasakan oleh subjek OB, ini sesuai dengan apa yang dikatakan Lefley (1996), bahwa dampak merugikan dari stigmatisasi termasuk kehilangan self esteem, perpecahan dalam hubungan kekeluargaan, isolasi sosial, rasa malu; yang akhirnya menyebabkan perilaku pencarian bantuan menjadi tertunda.

\section{Strategi Coping Dan Sumber Dukungan Pelaku Upacara}

Temuan penelitian ini menunjukkan bahwa coping yang dilakukan para pelaku, utamanya pelaku upacara rambu solo' besar, cenderung mengalami penurunan secara bertahap. Bentuk penurunan coping jelas terlihat dari orientasi kedua subjek (subjek TM dan DS) yang awalnya menggunakan coping berfokus pada masalah kemudian beralihopadasspping berfokus pada emosi dan dari coping adaptif beralih pad soping maladaptifPDF 
Pada mulanya, baik TM maupun DS menerapkan perilaku aktif sebagai cara mengatasai beban keuangan yang mereka derita seperti bekerja pada sektor informal dan kemudian beralih pada penjualan aset berharga baik berupa sawah dan ternak.

Tidak adanya aset berharga membuat keduanya kehilangan pekerjaan dan pemasukan sehingga kemudian beralih kepada mencari dukungan sosial secara instrumental dengan menggunakan sistem peminjaman "gali lubang tutup lubang". Meski, Carver dan Scheier (1989) memasukkan strategi peminjaman gali lubang tutup lubang sebagai coping berfokus pada masalah, namun jika melihat siklus yang berulang-ulang pada kedua subjek (subjek TM dan DS), maka strategi ini bisa menjadi maladaptif lantaran lebih berfokus pada pengalihan masalah dan pertahanan diri akan perasaan terancam secara emosional, bukan penyelesaian pada masalah inti, sebagai sumber stresor.

Mempertimbangkan temuan ini, peneliti lebih cenderung melihat strategi ini sebagai indikasi paling nyata, bahwa keadaan subjek yang parah dan sulit untuk berubah. Hal ini sejalan dengan penelitian yang dilakukan oleh Ostman dan Hansson (2001) bahwa penggunaan coping yang berfokus pada emosi (emotional-focusedcoping) lebih digunakan oleh anggota keluarga maupun penderita di mana mereka harus menerima keadaan sakit dirinya dan anggota keluarganya, kemungkinan lebih sesuai untuk keadaan penderita yang sudah kronis dan sulit untuk berubah.

Penggunaan emotional focus coping pada pelaku upacara juga senantiasa berubah-ubah dari coping yang adaptif seperti penerimaan dan turning to religion berarah kepada aktivitas perjudian. Bahkan untuk subjek DS, berlanjut pada penyalahgunaan alkohol. Tentang temuan ini, Ito, Miller, dan Pollock (1996) menyatakan bahwa penyalahgunaan alkohol merupakan wujud frustasi yang dapat timbul dari adanya kendala yang menghalangi pencapaian tujuan individu .

Temuan penelitian ini sejalan dengan penelitian Schwarzer dan Taubert (2002) menyatakan bahwa perilaku coping bersumber dari diri individu itu sendiri (internal coping) dan lingkungan (external coping). Internal coping terkait dengan kompetensi dan skill individu yang sebenarnya terkait dengan pola kepribadian yang mesti dimiliki individu sebagai syarat mutlak untuk melakukan coping terhadap segalarbentuk stresor terutama beban keuangan 
rambu solo' Sedangkan External coping terkait dengan perilaku coping yang muncul karena adanya dukungan sosial.

Jikapenggunaancopingberfokuspadaemosi, setelahsebelumnya menggunakan coping berfokus pada masalah mengindikasikan kondisi subjek sudah gawat dan tidak memungkinkan akan perubahan seperti halnya kedua subjek di atas (subjek TM dan DS) maupun penelitian yang dilakukan oleh Ostman dan Hansson (2001). Maka lain halnya dengan apa yang terjadi pada subjek dengan upacara sedang (tingkat minimal tana' bulaan) atau bahkan dengan upacara yang minim (subjek AS dan $\mathrm{OB}$ ).

Baik subjek AS dan OB, masing-masing terlihat bahwa penggunaan coping berfokus pada emosi yang mereka lakukan baik berupa penyangkalan (denial) maupun mengurung diri dengan aktivitas di kamar (subjek AS), merupakan cara masing-masing subjek dalam membendung dampak merugikan dari stigmatisasi terhadap dirinya maupun deprivasi pemenuhan emosional diri lainnya. Stigma negatif yang mereka (subjek AS dan OB ) dapatkan dari masyarakat adalah dampak tidak langsung dari pola coping berfokus pada masalah beban keuangan rambu solo', yang oleh masyarakat dianggap menyimpang dari ketentuan adat.

Menolak mengadakan rambu solo' yang besar, mempercepat upacara dan membatasi petua' baru yang datang, merupakan coping perilaku aktif, yang oleh Carver dan Scheier (1989), dianggap sebagai proses pengambilan langkah-langkah aktif untuk mencoba memindahkan, menghindari tekanan dan memperbaiki dampaknya. Bahkan jika ditinjau dari situasi subjek terhadap stresor, maka, coping yang mereka lakukan adalah preventif coping, yaitu jenis coping yang yang dilakukan jauh sebelum stres terjadi dan yang akan mungkin terjadi (Beehr \& McGrath, 1996). Namun oleh masyarakat adat, strategi coping, secara spesifik perilaku aktif yang mereka lakukan merupakan tindakan yang tidak pantas dilakukan oleh seorang tana' bulaan.

Konsekuensinya, mereka menjadi korban stigmatisasi,dan oleh karena itu mereka memerlukan coping emosional yang adekuat. Dalam penelitian ini, denial, merupakan strategi coping, yang mereka lakukan. Dengan mekanisme pertahanan tersebut, baik subjek AS dan OB, seakan ingin melakukan pembelaan dari atribusi negatif (stigma) yang ditujukan kepadanya. Kesan yang muncul dari pernyataan keduanya (subjek AS dan $\mathrm{OB}^{\text {B }}$ ) memperlihatkan penyangkalan 
sebagai pemenuhan atas deprivasi emosional dalam diri sekaligus pengabaian terhadap keadaan ancaman eksternal dari masyarakat dan menganggap kondisi berjalan baik-baik saja.

Temuan penelitian ini sesuai dengan pernyataan Bell (dalam Sarwono, 1991) bahwa hasil interaksi individu dengan lingkungan menghasilkan persepsi individu terhadap lingkungan tersebut. Jika persepsi itu berada dalam batas-batas optimal maka individu dikatakan dalam keadaan homeostatis (seimbang). Keadaan ini biasanya dipertahankan oleh individu karena menimbulkan perasaan yang menyenangkan. Sebaliknya bila individu dipersepsi oleh individu berada di luar batas optimal (overstimulation) atau di bawah (understimulation) maka individu akan mengalami stres dalam dirinya. Untuk itu maka individu harus melakukan coping untuk menyesuaikan lingkungan pada kondisi dirinya.

\section{Problem Psikologis Beban Keuangan Rambu Solo'}

Hasil penelitian menunjukkan bahwa secara umum, beban keuangan rambu solo' sebagai stressor, menyebabkan problem psikologis yang berbeda-beda pada setiap subjek. Perbedaan ini tidak dapat diartikan sebagai problem psikologis yang benar-benar berbeda melainkan merupakan proses yang terus berlanjut atau gradual. Pada mulanya, semua subjek yang melaksanakan upacara rambu solo' mengalami problem psikologis yang hampir sama, yaitu kondisi stres langsung ketika mempersiapkan upacara rambu solo'.

Selain dampak stress langsung seperti halnya di atas, Temuan penelitian ini juga menunjukkan bahwa kemungkinan lebih besar subjek dengan latar belakang rentan atau ketiadaan sistem sumber, seperti halnya tidak adanya atau minimnya penghasilan dan aset produktif, serta pendidikan yang rendah, yang melakukan upacara rambu solo' yang besar atau sempurna lebih cenderung menderita stres yang lebih berat dan mengarah kepada gangguan depresi ringan dibandingkan dengan para anggota masyarakat yang melakukan upacara rambu solo' tingkat menengah (standar minimal tana' bulaan) dan minim.

Penjelasan tentang hal tersebut adalah bahwa kejadian menekan (stressor) beban keuangan rambu solo' tidak menyebabkan problem psikologis secara langsung melainkan sangat tergantung pada kemampuan individu (karakteristik kepribadian) dalam mengahadapi peristiwareytangwidtialaminya dengan menggunakan

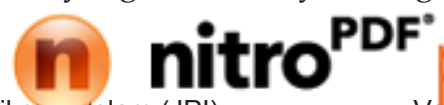


sistem sumber (resources system) yang ada. Hal ini juga sejalan dengan pandangan bahwa pengalaman traumatis dan menekan memiliki dampak pada kesejahteraan psikologis menekankan kepada peran penegah dari reaksi coping yang diberikan (Pasto dkk, 2000).

Pada subjek yang melakukan upacara besar seperti TM dan DS , gejala -gejala stres berat dan mengarah kepada depresi ringan, ditandai tidak hanya pada saat keadaan stres mempersiapkan upacara, melainkan berlanjut dengan ketakutan-ketakutan terhadap masa depan yang muncul secara berlebihan seperti Ketakutanketakutan atau kecemasan yang konstan soal pengembalian petua' sule dan hutang-hutang yang banyak kepada orang lain bahkan juga diperparah dengan keadaan frustasi dan putus asa yang berat terhadap situasi yang ada.

Keadaan pada subjek sejalan dengan yang diungkapkan Beck (1967) , bahwa depresi merupakan seperangkat pikiran negatif yang terdiri dari sikap negatif dan keyakinan negatif terhadap diri sendiri, dunia dan masa depan. Bahkan depresi kemungkinan muncul ketika individu tidak mampu menemukan solusi atas permasalahan yang dihadapinya.

Temuan lain dari penelitian ini terkait dengan problem psikologis yang muncul dari keterlibatan subjek dalam upacara rambu solo' adalah adanya perbedaan pola interaksi dalam masyarakat antara subjek yang melaksanakan upacara rambu solo' yang besar dan upacara yang menengah atau kecil. Pada subjek dengan upacara rambu solo' tingkatan rappasan sundun, seperti subjek TM dan DS, memiliki kecenderungan perilaku yang kontradiktif atau ambigu , yakni antara perilaku rendah diri (low self esteem) dan superior . Perilaku rendah diri pada subjek, akan muncul ketika berhadapan dengan saudara kandung atau sepupu. Sikap ini muncul dari persepsi subjek atas perbedaan tanggungan kerbau antara dirinya dan saudaranya. Selain itu kesenjangan antara tanggungan kerbau, perbedaan materi, tingkat pendidikan, pekerajaan menjadi variabel munculnya perilaku rendah diri pada subjek, terutama pada subjek DS. Namun, ketika berada di tengah-tengah masyarakat, sikap rendah diri pada subjek TM dan subjek DS akan berubah menjadi sikap superior serta percaya diri.

Sementara problem psikologis pada subjek akibat keterlibatan mereka dalam upacara rambu solo' yang menengah atau kecil

$$
\text { (n) nitro }{ }^{\text {PDF }}
$$

PSIKOISLAMKA, Jurnal Psikologı ıslam (JPI) 
diantaranya berupa sikap dan perilaku rendah diri yang lebih luas dan eksesif, tidak hanya tertuju pada keluarga besar melainkan juga pada masyarakat pada umumnya. Bahkan perasaan rendah diri yang terus menerus akan berlanjut pada penarikan diri (interpersonal withdraw) baik sebagian maupun dari keseluruhan hubungan interaksi dengan masyarakat.

Rendah diri dan penarikan yang terjadi pada subjek, dengan upacara sedang dan terutama sekali dengan upacara yang minim, memang lebih terkait dengan stigma yang melekat pada mereka. Hal ini sebagaimana yang dikatakan Lefley (1996), bahwa dampak merugikan dari stigmatisasi termasuk kehilangan self esteem, perpecahan dalam hubungan kekeluargaan, isolasi sosial, rasa malu, yang akhirnya menyebabkan perilaku pencarian bantuan menjadi tertunda.

Hal inilah yang dialami oleh subjek. Deprivasi akan kebutuhan disukai dan dimiliki terhadap masyarakat, menimbulkan keadaan tidak menyenangkan dan terancam bagi subjek AS dan OB, setiap kali berhubungan dengan lingkungan. Pengalaman menjadi pergunjingan orang-orang kampung setiap kali pergi melayat, hingga pengabaian dari keluarga besar terutama pada subjek OB, membuat subjek tersebut mempersepsikan lingkungan berada di luar batas optimal.

Hal ini sebagaimana yang dinyatakan Bell (dalam Sarwono, 1991) , bahwa apabila lingkungan dipersepsi oleh individu berada di luar batas optimal (overstimulation) maka individu akan mengalami stres dalam dirinya. Sehingga satu-satunya cara untuk terhindar dari keadaan terancam yang ditimbulkan dari proses interaksi ini adalah dengan melakukan penarikan diri (interpersonal withdraw). Penarikan diri interpersonal dalam perspektif psikodinamik dipandang sebagai upaya individu untuk terbebas dari penilaian terhadap tingkah laku dan pikirannya yang kurang "tepat".

Bahkan selanjutnya, penarikan diri dari orang lain dapat mengakibatkan kehilangan dukungan sosial dan kemudian bisa rentan terhadap pengaruh-pengaruh dari stres (Semiun, 2006) . Namun pada temuan penelitian ini, penarikan diri subjek sebatas pada lingkungan masyarakat adat yang mengancam. Pada subjek AS, ia terkadang juga mendapat dukungan sosial dari keluarga besarnya, sedangkan pada subjek OB, dukungan sosial dari isteri merupakan kekuatan sekaligus pemenuhan atas deprivasi kebutuhan untuk disukai dan dimiliki, yang tidak didapatkan dari keluarga besar dan 
masyarakat.

\section{Dinamika Problem Psikologis Dan Coping Pelaku Upacara Rambu Solo'}

Dinamika problem psikologis dan coping pelaku upacara rambu solo' sangatlah kompleks. Keputusan terlibat langsung dalam upacara, tidak didasarkan pada keputusan yang tiba-tiba melainkan melalui proses internal dalam diri yang sangat panjang. Sebab tidak semua subjek, yang memiliki karaketeristik sosio-demografi yang sama dalam penelitian ini melakukan upacara rambu solo' yang besar sebagaimana disyaratkan atau dianjurkan oleh keluarga besar dan dewan adat.

Temuan penelitian ini telah menemukan bahwa perbedaan tingkat upacara rambu solo' masing-masing subjek terletak pada perbedaan kebutuhan-kebutuhan yang mendasari perilaku ketelibatan mereka. Kebutuhan-kebutuhan yang dimaksud, yaitu kebutuhan untuk survive, love and belonging, power, freedom and fun (Glasser, 1998)

Lebih lanjut menurut Glasser (1998), bahwa beberapa di antara kebutuhan-kebutuhan spesifik tersebut ada yang dominan terdapat pada masing-masing individu dan sebagian lagi tidak. Dalam upacara rambu solo', para subjek yang melakukan upacara yang besar seperti TM dan DS memiliki kebutuhan untuk berkuasa yang dominan sebaliknya pada subjek yang melakukan upacara rambu solo' yang sedang dan minim memiliki kebutuhan untuk bebas (need to freedom) yang lebih menonjol. Penjelasan yang lebih mungkin mengenai perbedaan kebutuhan-kebutuhan dasar yang ingin dipenuhi subjek melalui upacara rambu solo' adalah bahwa kebutuhan-kebutuhan tersebut telah dimodifikasi oleh budaya dan pengalaman personal mereka.

\section{Kesimpulan}

Berdasarkan hasil penelitian maka dapat disimpulkan beberapa hal sebagai berikut :

1. Keputusan untuk melaksanakan upacara rambu solo' bukan merupakan keputusan yang dilakukan secara tiba-tiba, melainkan melalui proses internal yang panjang pada setiap individu

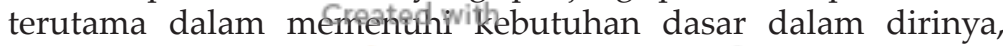


yaitu kebutuhan untuk survive, love and belonging, power, dan freedom.

2. Penelitian ini juga menunjukkan bahwa para pelaku dari berbagai tingkatan upacara tidak hanya menghadapi dampak langsung beban keuangan rambu solo' melainkan juga harus menghadapi berbagai dampak jangka panjang atau dampak tidak langsung sebagai implikasi dari ketidakmampuan subjek dalam mengatasi dan mengontrol permasalahan asal beban keuangan rambu solo' sebagai stresor.

3. Strategi coping yang dilakukan para pelaku, utamanya pelaku upacara rambu solo' besar, cenderung mengalami penurunan secara bertahap. Penyebab penurunan coping subjek disebabkan karakteristik kepribadian yang rentan dan deprivasi dukungan sosial.

4. Problem psikologis yang muncul dari keterlibatan subjek dalam upacara rambu solo' berbeda-beda pada setiap subjek.

5. Dinamika problem Psikologis dan coping yang terjadi pada pelaku upacara menunjukkan bahwa ketelibatan mereka dalam upacara rambu solo' telah melalui proses internal dalam diri yang panjang. Oleh karena itu masing-masing subjek telah memahami kondisi dan resiko yang akan mereka hadapi dari setiap keputusannya.

Berdasarkan kesimpulan dari hasil penelitian yang telah dikemukakan di atas, dapat diajukan beberapa saran sebagai berikut

1. Bagi pelaku upacara rambu solo'

Beban keuangan rambu solo' merupakan hal yang sangat berat karena dapat menganggu kesejahteraan hidup dari pelakunya. Bagi subjek diharapkan dapat segera berupaya mencari pertolongan yang lebih nyata dari keluarga-keluarga terdekat serta menghindari perilaku-perilaku yang tidak produktif seperti berjudi dan minumminuman keras, karena hal tersebut, tidak menyelesaikan yang ada.

\section{Bagi keluarga besar}

Keluarga besar hendaknya dapat menjadi pelindung dan membantu anggota keluarga yang melaksanakan rambu solo', tidak hanya dari beban keuangan rambu solo' saja tetapi juga dengan memberikan dukungan emosional ketika ada anggota keluarganya yang mendapat stigma yang buruk dari masyarakat karena upacara duka cita yang dilakukan

$$
\text { n } \text { nitro }^{\text {PDF }}
$$




\section{Bagi dewan adat}

Sudah saatnya dewan adat mempertimbangkan melaksanakan program jaminan jangka panjang berupa sistem jaminan ekonomi bagi setiap masyarakat adat utamanya dalam merintis pengelolaan "Bank petua'.

4. Bagi pemerintah kabupaten Toraja Utara

Hendaknya dapat mempertimbangkan regulasi berupa peraturan daerah yang dapat mendorong para pelaku usaha pariwisata untuk dapat berpartisipasi secara langsung dalam membantu keluarga -keluarga miskin yang akan melaksanakan upacara rambu solo'.

5. Bagi Peneliti selanjutnya

Bagi peneliti mendatang diharapkan dapat mempergunakan pendekatan penelitian lainnya berupa penelitian aksi partisipatif (PAR) maupun melalui program keterampilan kognitif.

\section{Daftar Pustaka}

Beck, A. T. (1967). Depression: clinical, experimental and theoritical aspects by Hoeber Medica Devision USA, Harper and Row Published Incorporated.

Beehr, T.A \& McGrath, J.E. (1996). The Metodology of research on coping: Conceptual, strategic and operational- level issues, In Handbook of coping theory, research, application, pp.127-145. Hemisphere, Washington, DC.

Carver, C.S., Scheier, M.F., \& Weintraub , J.K. (1989). Assesing coping strategies: A theoritically based approach, Journal of Personality and Social Psychology, 56, 267-283.

Chaplin, J. P. (1997). Kamus Lengkap Psikologi. (K. Kartini, Terj.). Jakarta: PT Raja Grafindo Persada.

Crider, A. B., Goethal, G. R., Kavanough, R. D., \& Solomon, P. R. (1983). Psychology. Illinois : Sott, Foresman \& Company.

Fan, J.X., \& Zick, C.D. (2004). The economic burden of health care, funeral, and burial expenditures at the end of life. The Journal of Consumer Affairs, 38 (1), 15-18.

Glasser, W. (1998). Choice theory: a new psychology of personal freedom. New York: Harper Côlins Publiseher. Inc. 
Glasser, W. (2005). Choice Theory site map. http://www.Choice theory. com/ct,htm. Diakses pada 7 juni 2011

Groenewald, T. (2004). A phenomenological research design illustrated. International Journal of Qualitative Methods, 3(1). Article 4. http://www.ualberta.ca/ iiqm/backissues/3_1/pdf/ groenewald.pdf. Diakses 15 juni 2011

Hawari, D. (2002). Manajemen Stres, Cemas, dan Depresi. Jakarta : Balai Penerbit FKUI.

Ito, T. A., Miller, N., \& Pollock, V.E. (1996). Alcohol and agression : A meta -analysis of the moderating effects of inhibitory cues, triggering cues, and self- focused attention. Psychological Bulletin, $120,60-82$.

Kobong, T. (2008). Injil dan Tongkonan: Inkarnasi, Kontekstualisasi, Transformasi .Jakarta: Gunung Mulia.

Koentjoro (2007). Berbagai jenis inquiry dalam penelitian kualitatif. Unpublished manuscript. Yogyakarta: Fakultas Psikologi Universitas Gadjah Mada.

Lefley, H.P. (1996). Family Caregiving in Mental Illness. Thousand Oaks. CA : Sage Publication.

Moleong, L. (2007). Metode Penelitian Kualitatif. Bandung: PT. Remaja Rosdakarya.

Moustakas, C. (1994). Phenomenological research methods. SAGE Publications. Inc Thousand Oaks.

Ostman, M., \& Hansson, L. (2001). The relationship between coping strategies and family burden among relatives of admitted psychiatric patients. Scandinavian Journal of Caring Sciences, 15, 159-164.

Parkes, C. M. (2001). A historical overview of the scientific study of bereavement. In M. S. Stroebe, R. O. Hansson, W. Stroebe, \& H. Schut(Eds.), Handbook ofbereavement research: Consequences, coping, and care (pp. 25-45). Washington, DC : American Psychological Association.

Pastò, L., McCreary, D., Thompson, M., (2000). Deployment stressors, coping, and psychological well-being among peacekeepers. Toronto: Defence Research and Development.

\section{Created with}


Rahmawati, D., (2006), Kejadian menekan dan strategi pengatasan masalah pada penderita kanker payudara, Skripsi. Yogyakarta : Fakultas Psikologi UGM.

Sarwono, S.W., 1991. Psikologi Remaja. Jakarta : Rajawali Press

Schwarzer, R., \& Taubert, S. (2002). Tenacious goal pursuits and striving toward personal growth: Proactive coping. In E. Frydenberg (Ed.), Beyond coping: meeting goal, visions, and challenge (pp.19-35). London: Oxford University Press.

Semium, Y. (2006). Kesehatan Mental 3. Yogyakarta: Kanisius (Anggota IKAPI).

Stroebe, M., Folkman, S., Hansson, R. \& Schut, H. (2006). The prediction of bereavement outcome: development of an integrative risk factor framework, Social Science \& Medicine, 63, 2440-51.

Stroebe, M. Schut, H. and Stroebe, W. (2007). Health outcomes of bereavement, The Lancet, 370, 1960-73.

Tempo. (2001). Mencuri Mayat di Nirwana (Rubrik selingan). Majalah Tempo, 2001.

Tulak, D. (2009). Kada Disedan Sarong Bisara Ditoke' Tambane Baka. Rantepao: Siayoka. 